\title{
COVID-19 and Thrombosis Predisposition
}

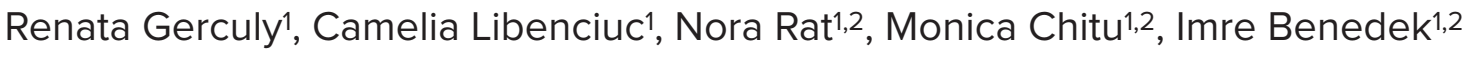 \\ ${ }^{1}$ Clinic of Cardiology, Emergency Clinical County Hospital, Târgu Mureș, Romania \\ 2 Center of Advanced Research in Multimodality Cardiac Imaging, CardioMed Medical Center, Târgu Mureș, Romania
}

\section{CORRESPONDENCE \\ Camelia Libenciuc \\ Str. Gheorghe Marinescu nr. 50 \\ 540136 Târgu Mureș, Romania \\ Tel: +40 265212111 \\ E-mail: camelialibenciuc@gmail.com}

\section{ARTICLE HISTORY}

Received: August 3, 2020

Accepted: September 5, 2020
Renata Gerculy • Str. Gheorghe Marinescu nr. 50, 540136 Târgu Mures, Romania. Tel: +40 265212 111, E-mail: gerculy_renata@yahoo.com

Nora Rat • B-dul 22 Decembrie 1989 nr. 76, 540124 Târgu Mureș, Romania. Tel: +40 265217 333, E-mail: ratnora@gmail.com

Monica Chitu • B-dul 22 Decembrie 1989 nr. 76 540124 Târgu Mureș, Romania. Tel: +40 265217 333, E-mail: iulia.chitu@yahoo.com

Imre Benedek • Str. Gheorghe Marinescu nr. 38 540139 Târgu Mureș, Romania. Tel: +40 265215551 E-mail: imrebenedek@yahoo.com

\begin{abstract}
The novel coronavirus disease first appeared in Wuhan (China) is an infectious disease spreading throughout the world, causing life-threatening conditions in vulnerable or even healthy individuals. The great impact of this virus on healthcare urges physicians to investigate all aspects of the disease in order to overcome its complications. A particularly investigated aspect of the SARS-CoV-2 infection is represented by the coagulation disorders among infected and critically ill patients. Several studies observed modified blood coagulation parameters such as D-dimers, fibrinogen, and coagulation times. Moreover, the severe thrombotic complications, mainly pulmonary embolism, could be responsible for the high mortality and poorer outcomes of COVID-19 infected patients. The aim of this article is to present the current knowledge related to thrombosis predisposition in patients infected with the new coronavirus.
\end{abstract}

Keywords: COVID-19, thrombosis, coagulation disorders

\section{INTRODUCTION}

COVID-19, the disease caused by the 2019 new coronavirus, first appeared in December 2019 and has since developed into a pandemic. To this date, the virus has caused the death of more than 500,000 people worldwide, and the pandemic shows no signs of slowing down. It is extremely challenging for clinicians and healthcare workers at the forefront to treat such patients with an increasing variety of symptoms. The novel coronavirus may potentially cause a mild upper respiratory tract disease similar to the common cold, or could lead to serious complications which include acute respiratory distress syndrome (ARDS), systemic inflammatory response syndrome (SIRS), multiple organ failure (MOF), and cardiogenic shock. Although the whole pathophysiological chain of this virus affecting the organism is not yet fully clarified, there is an observation that COVID-19 infected patients could be exposed to a higher risk of thromboembolic events. The large number of infected people worldwide and the greater impact of the pandemic on society as a whole, require thorough investigation into all aspects of the novel coronavirus disease. After the first months of fighting with the virus, it was hypothesized that coagulation abnormalities associated with the infection could contribute to increased mortality in COVID-19 patients. 
The new coronavirus has a known strain, SARS-CoV from the early 2000s, which infected 8,000 people and killed 774 of them, resulting in a case fatality rate of $9.6 \%$. Then, a few years later, in 2012, microbiologists isolated another strain in the Middle East, the MERS-CoV, which, compared to SARS-CoV, has a higher case fatality rate of about $35 \% .^{1,2}$ The novel coronavirus strain that appeared in Wuhan in December 2019 was designated by the WHO as COVID-19, and it infected more people than its two predecessors, by several orders of magnitude. The estimated case fatality rate of the novel strain causing the current pandemic is above $7 \%$. The clinical features range from asymptomatic to severe life-threatening manifestations. It is important to highlight that the patients' age, health status, and underlying conditions are important factors for the outcome of the disease. Accordingly, patients presenting comorbidities such as hypertension, diabetes mellitus, kidney failure, pulmonary diseases, and neurologic diseases are at a higher risk of poor outcomes..$^{3-5}$ Moreover, according to several studies, there is a higher predisposition to COVID-19 infection in patients with preexisting cardiovascular diseases. ${ }^{1}$

\section{UNDERSTANDING COVID-19 PATHOGENESIS}

To enter human host cells, COVID-19 binds to the angiotensin-converting enzyme 2 (ACE2) receptor membrane protein. Given the large number of ACE2 receptors in lung alveolar endothelial cells, once it enters the human body through the respiratory tract, it disrupts the lung's protective lining, causing the severe respiratory symptoms mentioned above. ${ }^{1}$ There are many other receptors mediating the entry of COVID-19 into the human cell, these being an organic part of the endothelium, which suggest the capital role of the endothelium in virus pathogenicity. Therefore, an important role of the drugs currently used to treat COVID-19 is to improve endothelial function. ${ }^{4-6}$ Acute infections represent temporary risk factors for thromboembolic events, COVID-19 being an important trigger in this regard. The infection-induced cytokine storm mediated through IL-6, IL-8, IL-10, IL-20, TNF- $\alpha$, as well as other inflammatory cytokines and chemokines, may initiate a series of pathophysiological processes in the body, precipitating a systemic inflammatory response syndrome (SIRS)., 4,9 The resulting sepsis, associated with hypoxia and immobilization, may induce a procoagulant state, leading to diffuse intravascular coagulation (DIC). DIC occurs when high amounts of cytokines activate monocytes and endothelial cells, followed by tissue factor activation and secretion of von Willebrand factor. ${ }^{10-12}$ Moreover, the presence of free thrombin in the blood stream and the lack of control of the natural anticoagulants lead to platelet activation and stimulation of fibrinolysis. ${ }^{10}$ The resulting hypercoagulable state associates to the other two elements of Virchow's triad present in severe COVID-19 patients: venous stasis and blood vessel wall injury as a result of ARDS. ${ }^{13,14}$

The International Society of Thrombosis and Haemostasis overt DIC (ISTH overt DIC) specifies DIC in sepsis as a coagulation disorder induced by infection, representing an acute systemic inflammatory response leading to endothelial injury, circulatory abnormalities, and subsequent tissue injury, which reduces life expectancy of the affected patients. ${ }^{15}$ The DIC Scientific and Standardization Committee (SSC) proposed a new diagnostic criteria for the earlier recognition of DIC, called "sepsis-induced coagulopathy" (SIC). According to several studies, both ISTH overt DIC and SIC scoring systems could be useful to identify patients at a higher risk for coagulation disorders, by observing PLT count, FDP/D-dimer, PT, fibrinogen, and SOFA score. As several studies described, almost three quarters of COVID-19-related deaths are meeting ISTH criteria for DIC, compared to survivors in whom this rate is only $0.6 \% .^{13}$

Additionally, a common finding in severe COVID-19 patients is T lymphocytopenia. It has been suggested that the virus may damage lymphocytes, mainly $\mathrm{T}$ lymphocytes, possibly explaining why elderly or immunocompromised individuals with one or multiple comorbidities are at higher risk to develop venous thromboembolism (VTE). ${ }^{8,9}$

Several animal studies have investigated the effects of viral infections on the coagulation process, and they observed that macaques inoculated with Ebola virions expressed TF in mononuclear phagocytes, thus triggering the activation of the coagulation system. Moreover, this and other animal models showed histological evidence of fibrin deposits in multiple organs such as the spleen, liver, lungs, and kidneys. ${ }^{16,17}$ These fibrin deposits could be associated with activated macrophages, which in turn are attracted by infected cells, demonstrating the interplay between inflammatory cells and the advent of systemic coagulopathy. In another experiment, mice infected with influenza virus showed platelet aggregation, pulmonary microvascular thrombosis, endothelial dysfunction, and hyperinflammatory cytokine responses. Therefore, the main mechanisms contributing to clot formation and fibrin deposition seem to be: increased activation of the procoagulant pathways, decreased activation of the physiological anticoagulants, and the suppression of fibrinolytic pathways. ${ }^{17}$ 


\section{STATUS QUO OF THE CURRENT SITUATION}

Autopsy reports from the Department of Pathology at LSU Health Sciences Center, New Orleans revealed some notable findings from COVID-19-related deaths. Gross examination of the lungs showed areas of thrombosis in peripheral small vessels. Microscopically, they found thrombotic microangiopathy and extensive extracellular fibrin deposition in the lung tissue. The most significant finding of heart examination was dilatation of the right cavities, indicating an increased pulmonary pressure possibly due to submassive pulmonary embolism. The patients were treated in the ICU and showed multiple underlying diseases such as obesity grade II-III, hypertension, diabetes mellitus type II, or chronic kidney disease. ${ }^{18}$

A study published in the Journal of Thrombosis and Hemostasis by Tang et al. investigated laboratory findings of 183 patients with confirmed novel coronavirus pneumonia (NCP). ${ }^{10}$ The mortality rate was $11 \%$. They compared the coagulation parameters including platelet count, prothrombin time (PT), activated partial thromboplastin time (APTT), antithrombin activity (AT), fibrinogen, fibrin degradation product (FDP), D-dimer levels, and the DIC score between survivors and non-survivors. The study showed increased levels of FDP and D-dimers in non-survivors compared to survivors. A longer PT and APTT was also observed in non-survivors. Afterwards, a DIC score (ISTH Criteria For Disseminated Intravascular Coagulation) greater than 5 points was present in $71.4 \%$ of deceased patients, compared to $0.6 \%$ of survivors. At the same time, in severe cases of NCP, the elevated levels of fibrin-related markers were associated with higher risk of death, highlighting the role of coagulation activation and secondary hyperfibrinolitic status for patient outcomes. ${ }^{10}$

A multicenter prospective cohort study from France compared the occurrence of thrombotic events between patients admitted to intensive care units (ICU) with CO-

TABLE 1. Outcomes of the main studies with endpoints related to coagulation abnormalities in COVID-19 patients

\begin{tabular}{|c|c|c|c|c|c|c|c|}
\hline Study & $\begin{array}{l}\text { Study } \\
\text { population/ } \\
\text { number of } \\
\text { included } \\
\text { patients }\end{array}$ & $\begin{array}{l}\text { Mean } \\
\text { age of } \\
\text { the study } \\
\text { population } \\
\text { (years) }\end{array}$ & $\begin{array}{l}\text { Clinical } \\
\text { diagnosis }\end{array}$ & Comorbidities & $\begin{array}{l}\text { Incidence of } \\
\text { coagulation } \\
\text { abnormalities }\end{array}$ & $\begin{array}{l}\text { Analyzed } \\
\text { parameter for } \\
\text { coagulation } \\
\text { disorder }\end{array}$ & $\begin{array}{l}\text { Patient } \\
\text { outcomes }\end{array}$ \\
\hline $\begin{array}{l}\text { Fox et al. }{ }^{18} \\
\text { (April 2020) }\end{array}$ & 4 & $44-76$ & ARDS & $\begin{array}{l}\text { Hypertension } \\
\text { Type II diabetes } \\
\text { Chronic kidney } \\
\text { disease } \\
\text { Obesity class 2-3 }\end{array}$ & $\begin{array}{l}\text { Thrombotic } \\
\text { microangiopathy } \\
\text { in all cases* }\end{array}$ & $\begin{array}{l}\text { Gross } \\
\text { examination } \\
\text { and microscopy } \\
\text { examination of } \\
\text { the lungs and } \\
\text { myocardium }\end{array}$ & Autopsy reports \\
\hline $\begin{array}{l}\text { Tang et al. }{ }^{10} \\
\text { (February 2020) }\end{array}$ & 183 & 54.1 & $\mathrm{NCP}$ & $\begin{array}{l}\text { Chronic cardiovascular } \\
\text { cerebrovascular, liver } \\
\text { and kidney disease } \\
\text { Malignant tumor }\end{array}$ & & $\begin{array}{l}\mathrm{PT}, \mathrm{APTT}, \mathrm{AT}, \\
\text { fibrinogen, FDP, } \\
\text { D-dimer }\end{array}$ & $\begin{array}{l}\text { 11.5\% died } \\
\text { 42.6\% discharged } \\
\text { 45.9\% remained } \\
\text { hospitalized in } \\
\text { stable condition }\end{array}$ \\
\hline $\begin{array}{l}\text { Helms et al. }{ }^{12} \\
\text { (March 2020) }\end{array}$ & 383 & 63 & $\begin{array}{l}\text { COVID-19 ARDS } \\
\text { Non-COVID-19 } \\
\text { ARDS }\end{array}$ & $\begin{array}{l}\text { Cardiovascular } \\
\text { diseases (48\%) } \\
\text { Neurological diseases } \\
\text { Kidney disease }\end{array}$ & $16.7 \%$ & $\begin{array}{l}\text { PLT, APTT, PT, } \\
\text { INR, D-dimers, } \\
\text { fibrinogen, AT }\end{array}$ & No data available \\
\hline $\begin{array}{l}\text { Spiezia et al. }{ }^{19} \\
\text { (April 2020) }\end{array}$ & 22 & 67 & $\begin{array}{l}\text { COVID-19 with } \\
\text { acute respira- } \\
\text { tory failure }\end{array}$ & $\begin{array}{l}\text { Obesity }(86 \%) \\
\text { Mechanically } \\
\text { ventilated patients } \\
(86 \%)\end{array}$ & $\begin{array}{l}\text { Significantly } \\
\text { higher fibrinogen } \\
\text { and D-dimer } \\
\text { levels vs. healthy } \\
\text { controls } \\
(p<0.0001)\end{array}$ & $\begin{array}{l}\text { Hb, PLT, PT/INR, } \\
\text { APTT, fibrinogen, } \\
\text { AT, D-dimer }\end{array}$ & $\begin{array}{l}1 \text { patient of } 22 \\
\text { died }\end{array}$ \\
\hline $\begin{array}{l}\text { Klok et al.20 } \\
\text { (April 2020) }\end{array}$ & 184 & No data & $\begin{array}{l}\text { COVID-19 } \\
\text { pneumonia }\end{array}$ & No data & $\begin{array}{l}\text { Composite } 31 \% \\
\text { VTE } 27 \% \\
\text { Arterial } \\
\text { thrombotic events } \\
3.7 \%\end{array}$ & PT, АРTT & $\begin{array}{l}13 \% \text { died } \\
12 \% \text { discharged } \\
\text { alive } \\
76 \% \text { remained } \\
\text { hospitalized }\end{array}$ \\
\hline $\begin{array}{l}\text { Cui et al. }{ }^{8} \\
\text { (March 2020) }\end{array}$ & 81 & 59.9 & NCP & $\begin{array}{l}\text { Hypertension } \\
\text { Diabetes } \\
\text { Coronary heart } \\
\text { disease } \\
\text { History of smoking }\end{array}$ & $25 \%$ & $\begin{array}{l}\text { PT, APTT, TT, } \\
\text { INR, fibrinogen, } \\
\text { D-dimer }\end{array}$ & $\begin{array}{l}\text { 10\% died } \\
79 \% \text { discharged } \\
11 \% \text { remained } \\
\text { hospitalized }\end{array}$ \\
\hline
\end{tabular}


VID-19 ARDS ( $\mathrm{n}=150)$ and those admitted for non-COVID-19 ARDS $(n=233)$. More than $95 \%$ of patients with novel coronavirus disease had increased D-dimer and fibrinogen levels. Sixty-four of 150 COVID-19 patients presented thrombotic complications during their stay in the ICU, with a high prevalence of pulmonary embolism. SIRS associated with high levels of fibrinogen was present in almost all of the cases and was responsible for coagulation abnormalities, as evidenced by progressive D-dimer level elevation. Interestingly, the coagulation activation pattern, as well as the mechanisms leading to DIC, were not identic in the two groups. In the cohort of non-COVID-19 ARDS patients, D-dimer levels were at a lower level, while PT, APTT, and AT were within normal ranges with higher fibrinogen blood levels. ${ }^{12}$

Another study, by Spiezia et al., evaluated coagulation abnormalities in a group of 22 patients with acute respiratory failure due to coronavirus disease, compared to a control group of 44 healthy individuals. Platelet count, INR, activated partial thromboplastin time, fibrinogen, and Ddimer levels were measured. The plasma levels of D-dimer and fibrinogen were markedly higher in COVID-19 patients compared to the control group ( $\mathrm{p}<0.0001) .{ }^{19}$

Another study, by Klok et al., included 184 patients admitted to the ICU with proven COVID-19 pneumonia, showing a $31 \%$ incidence of coagulation abnormalities. Both venous thromboembolism (27\%) and arterial thrombotic events $(3.7 \%)$ were defined by increased prothrombin time or activated partial thromboplastin time. ${ }^{20}$

Cui et al. retrospectively analyzed the coagulation parameters and lower limb venous Doppler ultrasonography of 81 patients with severe novel coronavirus pneumonia in Wuhan, China. ${ }^{8}$ Twenty (25\%) enrolled patients developed deep vein thrombosis in the lower extremities, 8 of which died. Patients who developed VTE were older and had increased APTT, higher D-dimer serum levels, and lymphocytopenia. ${ }^{8}$

The main results of the studies on coagulation abnormalities in COVID-19 patients are summarized in Table 1.

\section{THERAPEUTIC APPROACH AND PREVENTION OF COVID-19-INDUCED COAGULOPATHY}

According to ESC guidance, anticoagulation therapy in prophylactic doses should be considered in all hospitalized patients with COVID-19. On the one hand, preliminary data show that anticoagulant therapy among coronavirus-infected patients is associated with lower mortality. ${ }^{21}$ On the other hand, the thrombogenicity of COVID-19 is highlighted by the findings of multiple recent studies' observations, which show that venous thromboembolism occurs even in patients who receive anticoagulation medication in therapeutic doses from admission. In spite of anticoagulation therapy, many hospitalized COVID-19 patients developed serious thrombotic complications. ${ }^{12,19,22}$ Even so, considering the critically ill status and immobilization of hospitalized patients, thromboprophylaxis should be indicated independent of the presence of modified parameters suggesting thrombotic disorders. ${ }^{13,23}$ Furthermore, Tang et al. suggested that the use of low molecular weight heparin (LMWH) appears to be associated with better prognosis in severe COVID-19 patients meeting SIC criteria or with markedly elevated Ddimer levels..$^{10}$ Nevertheless, Barrett et al. questioned the efficacy of LMWH for treating severe COVID-19 coagulopathy and proposed the use of therapeutic anticoagulation with unfractionated heparin. Also, they propose fibrinolytic therapy with tissue plasminogen activator as salvage therapy when anticoagulation fails and no other options exist. ${ }^{13}$ Such approaches need to be investigated in the future due to the lack of solid evidence and consensus. ${ }^{13}$

A recent report investigated the association between treatment with LMWH for a minimum of seven days and mortality. Anticoagulated patients with a SIC score higher than 4 presented a mortality rate of $40 \%$, much inferior to non-anticoagulated patients in whom the mortality rate was $64.2 \%(\mathrm{p}=0.029) .{ }^{24}$

\section{CONCLUSION}

Coagulation disorders may significantly impact the outcome of COVID-19 patients. Increased D-dimer levels, elevated fibrin degradation products (FDP), and prolongation of PT time are common laboratory findings in COVID-19-infected patients with pneumonia, and they are associated with poorer outcomes. ${ }^{3,12}$ In addition, mild thrombocytopenia and shortened APTT also signal hemostatic abnormalities and should alert physicians to take appropriate measures. Since D-dimer levels are not specifically elevated in thrombotic disease, further investigations and especially imaging tests are required to either confirm or infirm venous thromboembolism. Cardiac ultrasound, an effective option to detect right heart overload in patients with high suspicion of $\mathrm{PE}$, is not always available as a routine test in emergency settings. ${ }^{7,23}$ A significant increase in D-dimer levels and an elevated Well-score, suggesting a high risk for developing deep vein thrombosis, should encourage clinicians to perform computed tomography (CT$\mathrm{PE}$ ) among suspected cases. 5,23

The current pandemic is still developing, and the pathomechanism, potential treatments, and prophylac- 
tic strategies to reduce the major impact of this illness are not yet completely elucidated. Further investigations are required to develop a better strategy against coronavirus related complications.

\section{CONFLICT OF INTEREST}

Nothing to declare.

\section{ACKNOWLEDGEMENT}

This research was supported via the research grant no. 103544/2016, contract number 26/01.09.2016, entitled "Increasing the research capacity in the field of vulnerable plaque imaging, based on advanced nanoparticles, fusion imaging and computational simulation - PlaqueImage", financed by the Romanian Ministry of European Funds, the Romanian Government and the European Union.

\section{REFERENCES}

1. Driggin E, Madhavan MV, Bikdeli B, et al. Cardiovascular Considerations for Patients, Health Care Workers, and Health Systems During the COVID-19 Pandemic. J Am Coll Cardiol. 2020;75:2352-2371.

2. Guarner J. Three Emerging Coronaviruses in Two Decades. Am J Clin Pathol. 2020;153:420-421.

3. Sardu C, Gambardella J, Morelli MB, Wang X, Marfella R, Santulli G Hypertension, Thrombosis, Kidney Failure, and Diabetes: Is COVID-19 an Endothelial Disease? A Comprehensive Evaluation of Clinical and Basic Evidence. J Clin Med. 2020;9:1417.

4. Giannis D, Ziogas IA, Gianni P. Coagulation disorders in coronavirus infected patients: COVID-19, SARS-CoV-1, MERS-CoV and lessons from the past. J Clin Virol. 2020;127:104362.

5. Danzi GB, Loffi M, Galeazzi G, Gherbesi E. Acute pulmonary embolism and COVID-19 pneumonia: a random association?. Eur Heart J. 2020;41:1858.

6. ten Cate H. Thrombosis management in times of COVID-19 epidemy; a Dutch perspective. Thromb J. 2020;18:7.

7. Conti P, Ronconi G, Caraffa A, et al. Induction of pro-inflammatory cytokines (IL-1 and IL-6) and lung inflammation by Coronavirus-19 (COVI19 or SARS-CoV-2): anti-inflammatory strategies. J Biol Regul Homeost Agents. 2020;34:327-331.
8. Cui S, Chen S, Li X, Liu S, Wang F. Prevalence of venous thromboembolism in patients with severe novel coronavirus pneumonia. J Thromb Haemost. 2020;18:1421-1424.

9. Qin C, Zhou L, Hu Z, et al. Dysregulation of Immune Response in Patients With Coronavirus 2019 (COVID-19) in Wuhan, China. Clin Infect Dis. 2020;71:762-768

10. Tang N, Li D, Wang X, Sun Z. Abnormal coagulation parameters are associated with poor prognosis in patients with novel coronavirus pneumonia. J Thromb Haemost. 2020;18:844-847.

11. Han H, Yang L, Liu R, et al. Prominent changes in blood coagulation of patients with SARS-CoV-2 infection. Clin Chem Lab Med. 2020;58:11161120.

12. Helms J, Tacquard C, Severac F, et al. High risk of thrombosis in patients with severe SARS-CoV-2 infection: a multicenter prospective cohort study. Intensive Care Med. 2020;46:1089-1098.

13. Barrett CD, Moore HB, Yaffe MB, Moore EE. ISTH interim guidance on recognition and management of coagulopathy in COVID-19: A comment. $J$ Thromb Haemost. 2020;18:2060-2063.

14. Schmidt M, Horvath-Puho E, Thomsen RW, Smeeth L, Sørensen HT. Acute infections and venous thromboembolism. J Intern Med. 2012;271:608-618.

15. Iba T, Levy JH, Warkentin TE, et al. Diagnosis and management of sepsisinduced coagulopathy and disseminated intravascular coagulation. J Thromb Haemost. 2019;17:1989-1994.

16. Beristain-Covarrubias N, Perez-Toledo M, Thomas MR, Henderson IR, Watson SP, Cunningham AF. Understanding Infection-Induced Thrombosis: Lessons Learned From Animal Models. Front Immunol. 2019;10:2569.

17. Semeraro N, Ammollo CT, Semeraro F, Colucci M. Sepsis, thrombosis and organ dysfunction. Thromb Res. 2012;129:290-295.

18. Fox SE, Akmatbekov A, Harbert JL, Li G, Quincy Brown J, Vander Heide RS. Pulmonary and cardiac pathology in African American patients with COVID-19: an autopsy series from New Orleans. Lancet Respir Med. 2020;8:681-686.

19. Spiezia L, Boscolo A, Poletto F, et al. COVID-19-Related Severe Hypercoagulability in Patients Admitted to Intensive Care Unit for Acute Respiratory Failure. Thromb Haemost. 2020;120:998-1000.

20. Klok FA, Kruip MJHA, van der Meer NJM, et al. Incidence of thrombotic complications in critically ill ICU patients with COVID-19. Thromb Res. 2020;191:145-147.

21. Kollias A, Kyriakoulis KG, Dimakakos E, Poulakou G, Stergiou GS, Syrigos K. Thromboembolic risk and anticoagulant therapy in COVID-19 patients: emerging evidence and call for action. Br J Haematol. 2020;189:846-847.

22. Llitjos JF, Leclerc M, Chochois $C$, et al. High incidence of venous thromboembolic events in anticoagulated severe COVID-19 patients. $J$ Thromb Haemost. 2020;18:1743-1746.

23. Obi AT, Barnes GD, Wakefield TW, et al. Practical diagnosis and treatment of suspected venous thromboembolism during COVID-19 pandemic. $J$ Vasc Surg Venous Lymphat Disord. 2020;8:526-534.

24. Tang N, Bai H, Chen X, Gong J, Li D, Sun Z. Anticoagulant treatment is associated with decreased mortality in severe coronavirus disease 2019 patients with coagulopathy. J Thromb Haemost. 2020;18:1094-1099. 